\title{
An Assessment of the Socio-Religious Roles of Women in a Traditional Igala Society
}

\author{
Okpe Nicholas Ojoajogwu, Ph.D \\ Department of Religious Studies, Kogi State University, Anyigba, Kogi State - Nigeria
}

*Corresponding Author: Okpe Nicholas Ojoajogwu, Department of Religious Studies, Kogi State

University, Anyigba, Kogi State - Nigeria

\begin{abstract}
The word woman can be used generally to mean any female human or specifically, an adult female human. In a traditional Igala Society, womanhood is understood as the period in a female's life which begins after she has passed through childhood and adolescence, and perceived from physical outlook to be able to bear a child; at this point in time she is ready to be given out in marriage. This study examines the place and roles of women in Igala Traditional Religion and Society. This study specifically investigates the socioreligious place and roles of women in Igala society especially as transmitters of moral and cultural values, diviners, priestesses, native doctors, midwives and hunters. The research discovered that women like men provide quality roles in various socio-religious sphares in Igala Traditional society. Thus the study using socio-religious evaluation assessed the roles, contributions and place of women in Igala indigenous religion and society. Specifically, the study investigated the contribution and roles of women in the development of Igala society.
\end{abstract}

Keywords: Women, Igala, Tradition, Religion and Society

\section{INTRODUCTION}

Igala indigenous religion is the belief and practices that is peculiar to the religious world-view of the Igala people. It is about the religion that is still practiced in traditional Igala environment. It is a fact that, in the traditional religious activities, men participate actively with minimal roles given to their women counterparts. This seeming relegation/marginalization of women can be attributed to the people's culture. In the early centuries, Igala culture undermined the importance of women in religious, political, economic and social activities. In fact, women suffered much from their male counterparts in this African patriarchal society. They were left out of so many things, no matter their age and spiritual status. In various aspects of human lives, women were relegated to the background. For instance, even if women had the same status with men in economic and social life, there was a limit to what role they could play in the Igala traditional society.

Some what like in early Greek society, women's status was slightly above that of the slaves as: The primary duty of women in ancient Athens was to marry and bear legitimate children so that the family might continue... the homes had separate women's quarters. When their husbands entertained guests, women were not permitted to be present... Attic literature of the period generally portrayed women as inferior and of dull and unpleasant character. It was thought that women should not be educated since that would make them more dangerous to men (Mamman 21).

The problem of discrimination and social prejudice has become a matter of concern to the women. This research is centered on the Place and Role of the Igala women which is predominantly about the Geographical Location of the Igala people. It shall take note of the historical and religious backgrounds and the fuller assessment of Women as medium of transmission of cultural and moral values, dividers, midwives, native doctors, priestesses, hunters and other roles played by women in Igala Religion and soceity.

\section{WhO THE IgAla PEOPLE ARE}

The Igala people are largely agrarian and semi-fishery and Yoruboid-speaking people located at one of the natural crossroads in Nigerian geography (East of River Niger), occupying the Niger-Benue 
confluence and astride of Niger in Lokoja, Kogi State of Nigeria. The area is approximately between latitude $6^{\circ} 30$ and $8^{\circ} 40$ North and longitude $6^{\circ} 30$ and $7^{\circ} 40$ East and covers an area of about 13,665 square kilometers (Oguagha P.A 1981).

Igala existed as a unit with other socio-cultural groups before the establishment of its dynasty as obtainable today. The establishment of the dynasty as visible in the Igala tradition is a result of its historical development. The basis for this assertion is the fact that several references have been made in connection with Igala and other kingdoms with similar tradition. We see more of this in the demographic encounters with other ethnic groups and peoples. In other words, the myths about Igala kingdom and other peoples in their historical development as kingdom in the remote past as well as in the more recent time give support to the above claim. This means that Igala existed side by side with other ethnic groups, and through interactions encountered them in various socio-cultural dimensions (Okpe 57).

Despite the fact that dates and figures are deficient in oral tradition, which has a peculiar style of narration of past events, it cannot be substituted with the Igala king lists or any other written records. An attempt to impose any modern method of historiography in determining the exact past of Igala would be a misrepresentation of history and tradition. Igala understanding and presentation of the past events is not synonymous to such methods. Contesting and rejecting the form of methodology employed by some authors like Clifford in determining the historical development of Igala sociopolitical system with the European standard of historiography, Boston noted: "Previous accounts of Igala tradition have used the Igala king lists as though they are basically equivalent to the linear time scale employed in European historiography, and they have attempted to translate the legends that records origins and foundation of the ruling house by the concepts of sequence and historical development that are associated with this type of time scale." (7).

This method is not devoid of difficulties especially when oral tradition is being forced into agreeing with such a time scale. And this constitutes the major problem in determining the span of the dynasty if we are to maintain the fact that the dynasty existed longer than the available written records by saying: "The principal objection to regarding the Igala king lists as an exact dynastic record is that their total time span does not coincide with the much longer span of time which seems reasonable for the history of the kingship on other historical grouds" (Boston 7). It means that using only the available written records to determine the length of Igala tradition and history as a kingdom or a strictly historical sequence of the Kingdom would be an artificial presentation and negation of Igala past. It therefore follows that the mythical period which precedes that in which the king lists is given, should be treated as real and important in the history of Igala kingdom even though it might not contain enough empirical data (Okpe 57-58).

The implication from the above is that even though the Igala ancestors of that period may be considered as non-historical figures in a literal and political sense, their roles and position in the dynastic establishment is as important as those after them. They could be well described as, "mythical archetypes of structural arrangements that must have taken a longer period of time to evolve than is suggested by the idiom of associated events with single reigns" (Boston 10). The implication of being solely dependent on the king lists as the prime source of Igala history is to disregard the role of mythology as seen previously in the history for "if the traditions are seen in their true perspective it once appears that the mythological phase of the past is of paramount importance, and that historical function is correspondingly subordinate to the political function of the myths contained in these traditions" (Boston 11). Thus we can affirm that mythical periods of Igala tradition should be treated as part of Igala history if the length and scale of their tradition of origin is to cover the meaningful facts in their tradition (Okpe 58).

\section{WOMEN IN IGALA TRADITIONAL RELIGION AND SOCIETY}

The Igala traditional religion which includes their way of life forms their main religion before the advent of Christianity and Islam. From the research conducted, majority of the respondents agreed that women share religious responsibility with their men counterparts in Igala today. In an oral interview session with Adejoh, from Imane, he said that while the educated Igala women in towns and cities today can boast that "what man can do, woman can also do" in the areas of politics, education and science, the uneducated women in Igala villages can also say the same slogan in areas of Igala traditional religious life. He further mentioned few areas where Igala women share religious 
responsibility with men. Such areas include healing, midwifery, divination, priestly role, upholding of traditional values and so on (Oral interview: Adejoh, 2017).

In another interview, Okpanachi said that if women are given opportunity, they can perform as much as their male counterparts in Igala Indigenous Religion. However, he noted that the nature of women has limited them in some areas. Such limitations he said, comes especially from their menstruation and childbirth which make them unclean to perform some religions role. He further explained that another reason why women are excluded from some religious roles is that they have tendency to talk too much which precludes them from being entrusted with secrets. He said however that aged and reputable women who are not known to be careless talkers are entrusted with some religious responsibilities.

\subsection{Women as Mediums and Diviners}

Research question on whether women can be diviners in Igala indigenous religion, suggests strong affirmation that women are diviners. Some of the respondents gave examples of shrines and even names of women who are diviners to such shrines. Adija, in a suburb of Eroke - Imane was mentioned as a diviner to a shrine called "agenyi". In the same vicinity another woman who is named after her shrine "Iye Adebu" is also mentioned as a diviner to a shrine called "Adebu".

Oral interviews conducted with both aged men and women in Dekina, Ankpa and Olamaboro respectively, discovered that women practice divination in Igala traditional religion. In his submission, Abimaje held that both men and women are possessed by deities in Igala society. He said that people resort to them freely for consultation during crises or illness. Like the traditional doctors, they are regarded as friends of their community. They play the role of counselors, judges, advisors, fortune tellers and revealers of secrets and as such held in high regard in the community. The economic advantage of the services of women diviners is enormous as they do not usually charge much. Adown (Interview) stressed that in Enjema, Emere and Odagbo in Ankpa Local Government Areas, the services of women diviners are always more available than that of their male counterparts because the men combine their service with farming as a means of survival. Their charges for their services are usually low.

\subsection{Women as Midwives}

It can easily be taken for for granted that midwifery is a basic function of women in Igala society. Thus, men do not compete on this ground with them. As such in Igala indigenous society women are local midwives. Maji (Interview) asserted that every old woman in Igala traditional society has some basic knowledge of midwifery transmitted to her either by her mother, aunty or neighbors who practiced midwifery. A particular woman called Kashuwa in Imane was renown for this practice, and eventually won the name Iye nurse (nursing mother). Personally interviewed, she said that she inherited the knowledge and practice of midwifery from her mother-in-law. She explained further that her duties include preparation before, during and after the birth. Presumably, she had practical knowledge about delivering babies and caring for them after birth. In her practice, she always prays to Ojo (God) to assist in removing evil influences and to grant a desirable good health to the mother and child.

On her own part Oja Awawo (Interview) maintains that she specializes in circumcision of male babies. She also stresses that she is a traditional obstetrician and cater for their ailments. The importance of women's role in this aspect of Igala traditional society cannot be over emphasized. This is because till today, every young lady between her first and third delivery usually invites her mother or mother-in-law to stay with her for a period of at least one month to nurse the new born baby. After the third delivery, the young lady through practical experience must have learnt how to take care of herself and baby.

\subsection{Women as Native Doctors}

In the Igala traditional society woman also practice medicine. Women like men undergo period of apprenticeship to become traditional doctors, healers or herbalists. These women like their men counterparts are often wrongly described as witch doctors. Traditionally men and women can be well trained in traditional medical practice, psychology and psychiatry. The traditional medical practitioners symbolize the hopes of their society; hopes of good health, protection and security from 
evil forces, prosperity and good fortunes and ritual cleansing when harm or impurities have been contracted. He mentioned names of women like Obaro who specializes in prescribing herbs for the healing of menstrual pains and in the treatment of skin infection called "Iwo" in Igala.

Virtually every village in Igala has a medicine man or woman. As friends of the community they are accessible to everybody and at all times. They are concerned first and foremost with disease, sickness and misfortunes which in the Igala experience are caused by mystical forces. The Igala traditional healers have therefore to diagnose the nature of the disease, discover its cause and apply the right treatment, together with a means of preventing its reoccurrence. It can be further explained that both physical and spiritual methods are applied to ensure good health. Traditional medicine women protect people from witchcraft and sorcery by supplying charms and other amulets. It can also be noted that many diseases, especially those related to mental disorders which cannot be cured in the modern hospitals or by orthodox means are being handled by Igala medicine men and women.

\subsection{Women as Priestesses}

In the time past Igala society, traditional priesthood was almost the activities of men. However, in the recent time this role in Igala indigenous society is now carried out by women to the extent that they appear to excercise more expertise at it than men. Examples of such activities of women is predominant in the eastern part of Igala land (Ankpa and Olamaboro Local Government areas).

There are several duties associated with women in this clime. These include: making sacrifices, offering prayers and conducting private and public rites at ceremonies. Women priestesses also give advice and perform judicial and political functions, in addition to caring for temples and shrine to which they are attached. They also fulfill their obligations as intermediaries between their people and the spirit world. It can be added that because of the nature of women in the aspect of their menstruation and childbirth which sometimes make them unclean, women who have reached menopause are commissioned as priestesses in Igala traditional religion. It can be further added however that this does not apply in all cases as some women are called even before their menopause.

\subsection{Women as Hunters}

Hunting, in human history, is considered one of the earliest occupations of man. This is also the perception in Igala Soceity. Secondly, hunting is perceived as an occupation reserved for men such that a woman may not dare it. However, this convention is overtaken in a traditional Igala society as there are some women who deliberately go for game and succeed in bringing some game to the table at home. In other words, women may not engage in commercial hunting, but some when opportunity provides, hunt game for family meal. Be that as it may, the role of women as hunters in Igala traditional society is not well pronounced from the assertion of those interviewed. For instance, Etila said that women play other roles in helping their hunting husbands but not actually carrying gun and other hunting tools like their husbands. In this perspective, he observed that during hunting women endure the pains of loneliness as they abstain from sex with their husbands. Their hunting husbands also avoid eating their food when they are in their menstrual period. The consequences of such violation may include fruitless hunting, injury during hunting, or serious illness. Other role played by Igala women in hunting also include caring for children while their husbands are away in the forest for some weeks or even months.

\subsection{Other Roles of Women}

Among other roles played by women in Igala traditional religion include transmission of Igala cultural values. If the saying that women are at the forefront of the education of children is anything to go by, then it is to be taken for granted that the inculation of cultural and moral values is one of the major roles being played by women in the Igala Soceity. Majority of the respondents to our research endavour agreed with the above role of women. They comment on the role played by women in teaching the children the native language and other Igala cultural values like greetings, cooking, tying of wrappers, and respect for elders. Achagba (Interview) said that while on the farm or at work, women are at home taking care of children; they punish children who go wrong and encourage those who are hard working in helping to do domestic works. This implies that women have more times for their children than the men.

In children up-bringing, mothers play more roles. That is why in Igala society, women whose daughters marry as virgin are rewarded with nine yards of wrappers. Similarly, women take more 
resposiblity for dissobedient and wayward children; mothers are usually blamed if their children become deviants (Agene Interview).

Women in Igala traditional society are also up-holders of traditional values. For example Akor (23) argued that a lot of festivals abound in Igala traditional religion. A good number of them are in honor of important divinities and ancestors of relevance. Finally, from the preceding discussion, it is clear that women in spite of their occasional uncleanness play significant role in Igala indigenous religion. This is antithetical to the feminist argument of women's marginalization.

\section{SUMMARY AND CONCLUSION}

It is usually argued that women are in a state of continuous effort for emanicpation especially women in the non western environment in social, religious and other attendant discriminations in traditional societies. This is usually traced back to the earliest times when women were seen as weaker sex who could not perform certain functions nor fill certain religious positions which were exclusively reserved for their male counterparts. From the oriental world, it can be observed that women are kept behind the veil. This is similar in Jewish tradition, where women are not regarded as equal to their male counterparts; the Jews had a rigid masculine concept of God who was the God of Abraham, Isaac, and Jacob, but not the God of Sarah, Rebecca, and Rachael. To St. Paul, it was a taboo for women to speak in the church. She was to ask her husband at home if there was anything that she wanted to know. Similarly, in Islam, women could only lead prayers for a congregation of women. And in the mosque women are not to stand in the same row with the men but separately behind the rows of men. These are the prevailing situations in many societies and religions which make it to look as if it is same all over. However, the situation is not completely the same in Igala indigenous religion and society where women play significant roles. Women in addition to having an intimate knowledge and experience of the spiritual life of the people also play significant and relevant role in the religious life of their people as ritual specialists and up-holders of the moral values of the Igala community. Therefore, the negative perception arising from the overall understanding of women position as a concept of impure blood must be overcome through studies of societies where they are already majoring significantly like we have seen in Igala society.

\section{Conclusion}

This work which is about the socio-religious roles women play in Igala society has enlightened us to be wary of sterotype and prejudices about the position and roles of women. This research has drawn attention to the significant role women play in Igala indigenous society. As opposed to the general feminist argument of women's marginalization, the study revealed that there are women who occupy important positions in Igala traditional religion as priestesses, diviners, midwives, native doctors and up-holders of community norms and traditions. The research also showed that women of childbearing age can occupy any position of leadership in Igala traditional soceity as against some myths which restrict women's access to sacred places based on the concept of impure blood.

It is our belief therefore, that this work will go a long way in helping more people to positively rethink their stand on the issue of women leadership and place in the Igala indigenous society and other fields of endavour. It is hoped that with this research there will be more interest in the activities of women among scholars for further investigation into the role of women in other social climes towards enhancing the significant contribution of women to humanity as a whole.

\section{REFERENCES}

[1] Ajayi, J.F et al. Ed. A Thousand years of West African History. Lokoja: Bemise Press, 1965.

[2] Ako, Sunday Abu. Dilemma of Women in African Society. Ankpa: Sanitos Press, 2001.

[3] Babangida, Mariam. Workshop to Prepare Blue Print on Women Education. Nigeria News Letter (April 1988): $3-4$.

[4] Crowder, Michael. The Story of Nigeria: Ibadan Faber and Faber, 1966.

[5] Matthew, Henry. Ed. Commentary on the Whole Bible. America: Hendrickson Publisher, 2003.

[6] Ogba, A.S. 500 Years of Ankpa History. Lokoja: Bobby Press, 2007.

[7] Okpe, Nicholas Ojoajogwu. Social and Cultural identity of An African Society: The Igala people of Nigeria Frankfurt am Main. Iko-verlag for Interkulturelle Kommunikation, 2006.

[8] Okwoli, P.E. Introduction to Igala Traditional Religion. Anyigba: The Pastoral Centre, 1996. 
[9] Ursula, King. Ed. Women in the World's Religions. Past and Present. New York: Paragon House, 1987.

[10] Victor, Alewo Adoji. The Man my People: A Compendium on Late Dr. Steven Makoji Achema. Lagos: Kay Graphic 2004.

\section{Articles in Journals}

[1] Agih, Isaac A. "Women Empowerment.”Ankpa Journal of Arts and Social Sciences 2.2 (Feb. 2005): 16-22.

[2] Akpata, S.I. "Gender Disparity in the Management of Educational Institution in Nigeria: The Challenges of the $21^{\text {st }}$ Century." Ankpa Journal of Arts and Social Sciences 2.1 (March, 2004): 103 - 114.

[3] Alana, Olu Emmanuel. "What is wrong with this Picture Paul Instance that Women Should Not Lead in the Church" Nigeria Journal of Christian Studies 2 and 3 (2006 and 2007): 1 - 16.

[4] Bello, A.A. "The Prerequisites for Women in Leadership.”Teacher Education Journal 12 (2006): 65 - 72.

[5] Ekejuiba, F. "Women in the Context of Nigeria Rural Development."Journal of Public Administration and Local Government 5.1 (1987): 22 - 30.

[6] Felix, L.K. “Women Empowerment: An Interactive for Development."NASH Journal 4.2 (Dec. 2006): 35-39.

[7] Joseph H. Mamman. "The Ministry of Women in the New Testament: A Case for against Women Ordination in the Catholic Church." The Nigerian Journal of Theology 20 (June, 2006): 21 - 34.

\section{AUTHOR'S BIOGRAPHY}

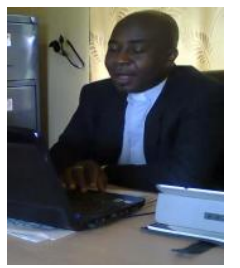

Dr. Okpe, Nicholas Ojoajogwu, is a Seniour lecturer with Kogi State University, Anyigba, Kogi State, Nigeria. His special area is Ethics in Humanities within Religion and Society in the department of Religious Studies. He obtained his degrees from prestigious Univeristies in Germany between 1994 and 2007. He has authored about fourteen books and published several articles in both local and international journals. He has also delivered many papers at international conferences. He wrote his

$\mathrm{PhD}$ thesis with the title: "The social and cultural Identity of an African Society - The Igala People of Nigeria". This was published concurrently in Frankfurt (Germany), London (UK) and New York (USA) in 2006.

Citation: Okpe Nicholas Ojoajogwu. "An Assessment of the Socio-Religious Roles of Women in a Traditional Igala Society" International Journal of Managerial Studies and Research (IJMSR), vol 5, no. 8, 2018, pp. 186-192. http://dx.doi.org/10.20431/2349-0381.05080017

Copyright: (C) 2018 Authors. This is an open-access article distributed under the terms of the Creative Commons Attribution License, which permits unrestricted use, distribution, and reproduction in any medium, provided the original author and source are credited. 